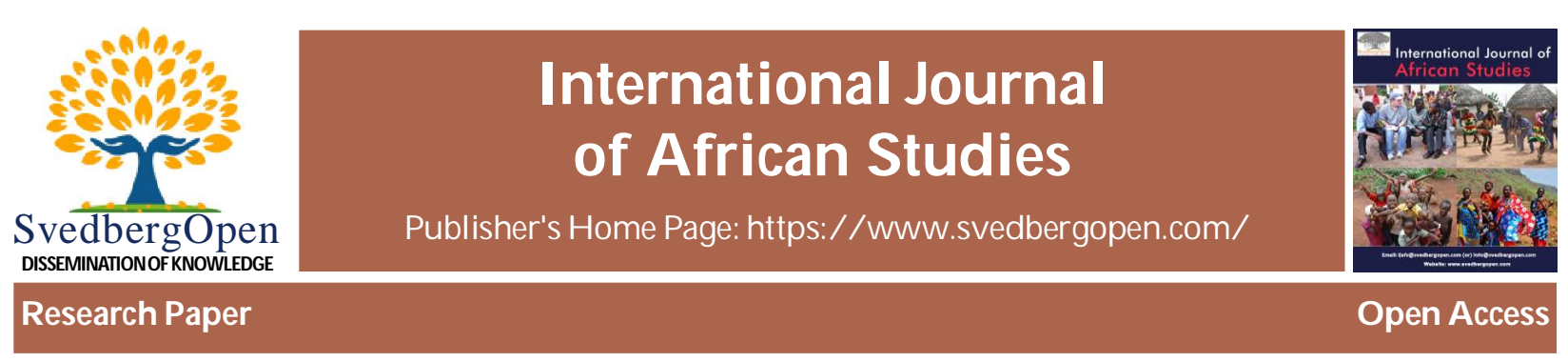

\title{
Eco: The Single Currency Agenda in West Africa
}

\author{
Adetutu Talabi ${ }^{1 *}$ \\ 'Babajide Koku \& Co., Nigeria. E-mail: talabiadetutu@gmail.com
}

\section{Article Info}

Volume 1, Issue 3, September 2021

Received : 27 February 2021

Accepted : 02 August 2021

Published : 05 September 2021

doi: 10.51483/IJAFRS.1.3.2021.62-66

\section{Abstract}

The Economic Community of West African States (ECOWAS) community agreed to embrace the ECO as its single currency and set the deadline for 2020. In this regard, this article outlines the reasons for currency integration in West Africa as well as the benefits and costs of currency integration. This article also points out the legal, structural and political constraints affecting the implementation of a single currency in the region. Finally, the article concludes by recommending solutions to these constraints.

Keywords: ECOWAS, Economic Integration, West Africa, West African Currency

$$
\begin{aligned}
& \text { (C) } 2021 \text { Adetutu Talabi. This is an open access article under the CC BY license } \\
& \text { (https://creativecommons.org/licenses/by/4.0/), which permits unrestricted use, distribution, } \\
& \text { and reproduction in any medium, provided you give appropriate credit to the original author(s) } \\
& \text { and the source, provide a link to the Creative Commons license, and indicate if changes were made. }
\end{aligned}
$$

\section{Introduction}

The ECOWAS came into existence in 1975 under a treaty agreement signed on the 28th day of May 1975 in Lagos, Nigeria. Currently, the community comprises fifteen sovereign West African States, namely: Benin, Burkina Faso, Cape Verde, Côte d'Ivoire, the Gambia, Ghana, Guinea, Guinea-Bissau, Liberia, Mali, Niger, Nigeria, Senegal, Sierra Leone and Togo. The countries comprise English speaking countries (Anglophone) and French Speaking Countries (Francophone).

Over the years, the central aim of the region has been the total integration of all economic activities for the progress and development of the West African region. Member states agreed that these objectives would be achieved by first establishing a free trade area, customs unions, a common market and ultimately a monetary union. Therefore, it is essential first to outline the development of monetary integration within the region.

\section{Currency Integration in West Africa}

In 2000, the countries in the economic bloc expressed their desire to speed up the process of monetary integration which was initiated in the early 1980s under the auspices of the ECOWAS monetary cooperation program ${ }^{3}$. This led to the establishment of the WAMZ which comprised of the English Speaking Countries. The West African Money Institute was established to coordinate and supervise the WAMZ program ${ }^{4}$. The French speaking countries already had a

Revised Treaty of the Economic Community of West African States (Ecowas) (Cotonou 1993).

Article 3, Revised Treaty of the Economic Community of West African States (Ecowas) (Cotonou 1993).

Mwanji P Fwangkwal (2014). "Monetary Integration in the ECOWAS" Understanding Monetary Policy Series No. 37, 10 ${ }^{\text {th }}$ Edition,

Monetary Policy Department of the Central Bank of Nigeria.

*Corresponding author: Adetutu Talabi, Babajide Koku \& Co., Nigeria. E-mail: talabiadetutu@gmail.com 
monetary union termed the West African Monetary Union (WAEMU) and they had adopted a common currency (The CFA). This then crystallized into a two-phased project. Under the first phase, a single currency called ECO was to be launched by the member states of WAMZ and in the second phase they were to merge with the member states of WAEMU to create a single currency in all 15 ECOWAS member states in $2020^{5}$.

Sadly, this strategy was abandoned due to insufficient preparation among the WAMZ states. Consequently, they decided to change strategy by rescheduling 2020 for the creation of a single currency in the whole of West Africa at once.

Interestingly, member states of WAEMU have taken the bull by the horn and declared that in the year 2020, its currency would now be known as the "ECO". They have declared that the currency would remain pegged to the Euro in order to guarantee its stability.

The West African Money Institute set out ten criteria that needs to be met before countries under WAMZ can implement the single currency agenda some of which are:

- A single-digit inflation rate at the end of each year

- A fiscal deficit of no more than $4 \%$ of the GDP.

- A central bank deficit-financing of no more than $10 \%$ of the previous year's tax revenues

- Gross external reserves that can give import cover for a minimum of three months. ${ }^{6}$

Unfortunately, only Ghana has been able to achieve the first 4 criteria in a single fiscal year.

\section{Why a Currency Integration Might Be Necessary in West Africa}

The choice of West African leaders to embark on monetary integration is that they believe that it can solve the monetary problems facing these countries. We will now look at some of the monetary problems of West African countries:

Constraints of the International Monetary System: West African countries, like most other developing countries are not immune to monetary shocks caused by policies implemented in the rest of the world. There is no doubt that the COVID-19 pandemic would change the face of the global economy and this will be reflected in the International Monetary systems. These decisions would be taken by the industrialized countries and such decisions always causes either an appreciation or depreciation in the currencies of African countries particularly in West African Countries.

A single currency can offer a chance, to put up a "collective and effective front" against these disruptions.

Lack of Independence of the Central Banks: The lack of Central Bank independence tends to affect the credibility and the effectiveness of monetary policy and its impact on the economy. The Central Bank Independence index calculated for West African countries gives the following scores: Guinea-0.63, Ghana-0.50, Nigeria-0.44, against an average of 0.47 in Africa?.

Non-Convertibility of Currencies: Exchange rates in the region are relatively volatile, most of the eight currencies used in the 15 countries of the West Africa region are not convertible. Convertibility is defined as the possibility to freely exchange a country's currency for foreign currencies, thereby fostering better integration in the world economy. Monetary integration will help to address the issue of multiple currencies and exchange rate fluctuations ${ }^{8}$.

Weak Financial Management Capacity: There have been weaknesses noticed in the definition of objectives and the organization of the financial markets of each country. With the emergence of trans- border banks in the sub-region, it has become a real challenge for West African Monetary authorities tasked with preserving financial stability to supervise these institutions. Memoranda of Understanding have been signed by various supervisory authorities in the subregion, but their implementation remains inadequate ${ }^{9}$.

The above problems are problems that no West African country might be able to solve by itself even the giant of Africa; Nigeria because these problems require a supra national approach before it can be solved, hence the need for monetary integration in West Africa.

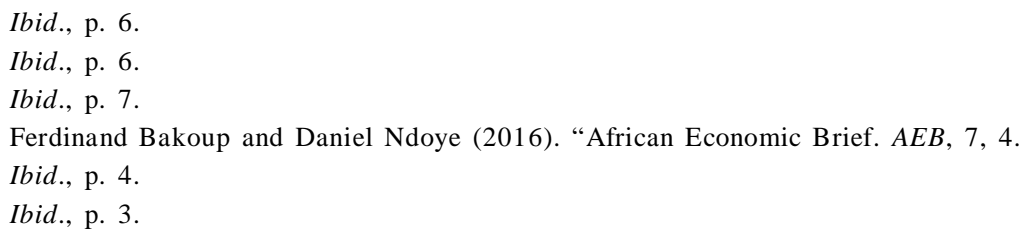




\section{Benefits of Currency Integration}

Currency integration confers several benefits on member states ${ }^{10}$. The success of the Euro shows that the scheme is feasible and can work. Some of these benefits are highlighted below:

Elimination of Exchange Rate Uncertainty: Volatile swings in the exchange rate can destroy the profitability of exports (e.g., rapid appreciation). Exchange rate uncertainty undermines business confidence in investing. In the absence of multiple currencies and exchange rate adjustment, there would be increased trade and foreign direct investment which would reduce capital flight to other countries. Therefore with a single currency, business confidence should improve leading to greater trade and economic growth. ${ }^{11}$

Lower Transaction Costs: With the use of a single currency, countries would be able to enjoy economies of scale due to expected increase in the volume of trade for goods and services amongst member states. Increased trade among member states would lead to high growth rate and improve per capita income. Consequently, there would be minimized transaction costs. These transaction costs are in form exchange rate losses that arise from currency fluctuations.

Independence of Monetary and Fiscal Policies: With the adoption of a single currency, no government will have control over its monetary policy. This will insulate policy formation from the influence of National Politics. The independence of the monetary authority will help curb inflation and ensure price stability. This is because strict regulations would hinder National Central Banks from funding huge government budget deficits thereby providing an avenue for maintaining macroeconomic stability.

\section{Costs of Monetary Integration ${ }^{12}$}

Monetary integration has tremendous benefits, there are however some disadvantages to the adoption of a single currency in West Africa and they are as follows

Loss of Autonomy Over Monetary Policies: By having a single currency within the region, countries may lose control over one of its main economic instruments. No longer will they be able to react to inflation by raising interest rates, as interest rates will have to be set centrally according to what the whole single currency area requires.

Loss of Revenue: Countries that are heavily reliant on fees gotten from custom duties will lose revenue accruing from the implementation of common external tariffs.

\section{Legal, Structural and Political Impediments to the Adoption of the "Eco"}

The countries under the WAEMU economic bloc are ahead of other African states when it comes to currency integration. These countries have used the same currency for a long time and have a common monetary policy. Unfortunately, the achievement of currency integration has been slowed down in WAMZ region due to certain factors. Some of them are outlined below:

Differences in National Laws ${ }^{13}$ : The differences in National business, trade and investment laws have made currency integration impossible for the WAMZ countries. Lack of unified laws would complicate business decision-making because institutions and individuals engaged in business transactions in many countries may have to seek legal advice on different legal regimes within the economic community. It therefore means that companies and individuals would have to adhere to different National Standards leading to increased operational costs. Countries that seek economic integrations must have its laws unified to an extent. For example; Mali, Burkina-Faso and Benin Republic under the WAEMU economic bloc have made great strides with economic integration and harmonization of their National Legislation. Article 3 (2) (a)-(d) of the ECOWAS Revised Treaty of 1993 provides that member states are to harmonize their policies and laws in order to achieve the objectives of the community. Twenty seven years after, these obligations have still not been fulfilled.

Pluralism of Economic Integration in the West African Sub-Region ${ }^{14}$ : West Africa is reported to have the largest number of intergovernmental organizations. This is one major impediment to currency integration. Countries belong to more than one regional bloc. This has resulted in the duplication of responsibilities and potentially conflicting

10 Integration https://www.academia.edu/11458996/Advantages_and_Disadvantages_of_single_currency_07?auto=download

11 Mwanji P. Fwangkwal (2014). Monetary Integration in the ECOWAS. Understanding Monetary Policy Series No. 37, 10 $0^{\text {th }}$ Edition, Monetary Policy Department of the Central Bank of Nigeria. p. 19.

12 Ibid., p. 4.

13 Dr Aniel Ikpang "Legal Impediments to full Economic Integration in West Africa" (49 ${ }^{\text {th }}$ Annual Nigerian Association of Law Teachers Conference).

$14 \quad$ Ibid., p. 11. 
commitments. Although the ECOWAS and WAEMU signed a general cooperation agreement in May 2004 to enhance the coordination and harmonization of their programs. The two bodies have in fact made efforts to rationalize their programs and avoid duplication. This agreement created a Joint Technical Secretariat to oversee the coordination of the integration policies. This has however not fully addressed the problem.

For example, when WAEMU announced that it had adopted the "ECO" to kick off in 2020, it was agreed that the currency is to be pegged to be Euro to ensure stability. The countries under the WAMZ economic bloc consequently rejected the "ECO" as a single currency in West Africa on the grounds that the WAEMU contravened the terms for the adoption of the currency as stated in Revised ECOWAS Single Currency Program.

Lack of Legal Mechanisms to Compel Compliance with Treaty Obligations ${ }^{15}$ : The ECOWAS treaty and its other legal instruments make no provision compelling member countries to ratify legal instruments promulgated by the ECOWAS. For example, while some member countries have ratified the legal instruments such as the Statute, others are yet to ratify and domesticate some of the legal instruments which are pre-requisites for monetary integration in the sub region. There are equally no sanctions available compelling member countries to fulfill their obligations of meeting the criteria for the integration of their currencies.

Political Instability ${ }^{\mathbf{1 6}}$ : Over the years, ECOWAS had to direct her energy and resources to resolving political crises within the region. There have been civil wars in Sierra Leone, Liberia, Cote d'Ivoire and Cape Verde. There are also issues of insurgency in the Northern part of Nigeria. These have rather occupied the minds of the leaders than the single currency issue. For instance the recent power tussle in Cote d'Ivoire was one of the distractions to the community development plan.

Lack of Political will Among the ECOWAS Nations: There is lack of political will among the ECOWAS nations to implement such an articulated program for economic growth and development. This is because states are unwilling to let go of their powers and sovereignty to the supranational body, which is the ECOWAS. ${ }^{17}$

Inadequate Infrastructure: Inadequate infrastructure in member countries poses a major challenge to adopting a single currency in West Africa. The region lacks adequate infrastructure in transportation, information communication technology and energy. This constitutes a major hindrance to regional integration and economic growth. Also, the industrial and manufacturing sectors are also not vibrant enough to create the needed employment that will accelerate economic growth and development in the region.

Loyalty to Previous Colonial Masters: The announcement by the WAEMU countries on its decision to adopt the "eco" without the other ECOWAS countries and have it pegged to the Euro is a demonstration that they would rather remain loyal to France that form new alliances with their neighboring countries. It is no surprise that the WAMZ countries pulled out of the single currency agenda as a result of this.

Fear of Domination by Stronger States: The weaker nations fear that their sovereignty and freedom might be in danger if they form a single currency union with more powerful states. Such fear might be compounded by historical, sociocultural and language differences. There exists a strong potential for one group to dominate the other. That is, Anglophone vis-à-vis the Francophone countries. This poses a great challenge to the actualization of single currency in the region. ${ }^{18}$

\section{Conclusion/Recommendations}

Economic integration has greatly contributed significantly to the growth and development of the West African subregion. Regional economic integration policies such as non-tariff on goods, free movement of people and goods within the region, and removal of barriers to trade among members have helped to strengthen the economic ties among member countries. The adoption of a single currency will further strengthen the economic ties among member countries. It would however prove impossible to attain the single currency without addressing these legal issues. My recommendations are as follows:

- The regional enforcement mechanisms of the community needs to be re-visited and strengthen to include sanctions to ensure that member states comply with treaty obligations such as harmonization of laws and policies.

- The multiple regional economic integration organization should be streamlined. It is obvious that there is a power tussle between the ECOWAS and WAEMU, the recognition of both organizations as the co-drivers of the regional

15 Ibid., p. 11.

16 Abdullahi Shehu Yusuf (2018). ECOWAS Single Currency and the Political Constrains. International Journal of Academic Research in Business and Social Sciences, 8(9), http://dx.doi.org/10.6007/IJARBSS/v8-i9/4636. Accessed on January 12, 2020.

17 Ibid.

18 Ibid. 
economic efforts in West Africa has more advantages that disadvantages this is because WAEMU countries are more loyal to themselves and their former colonial masters than to the ECOWAS itself. An example of this can be seen in the decision of WAEMU to peg its new eco currency to the Euro without considering the fact that the WAMZ countries would be hesitant to change its currency to the ECO due to this development, thereby defeating the last objective of the ECOWAS which is monetary integration.

- The challenges of distrust and suspicion between members must be tackled. Except all countries of the ECOWAS are seen and treated as equal, the fear of domination will continue to linger in the region. Member countries must be seen to have equal rights in all matters that concern the union.

- Member countries are to fix their infrastructure deficiency in order to ensure the free movement of goods and people. This must be done in line with the adoption of the single currency because improved infrastructure ensure free movement of goods and people. It will also attract broad-based investment that would accelerate growth and reduce poverty in the region.

- Legal Trainings should be made available on the legal framework and structure of the ECOWAS and its organs as most lawyers are largely unaware. Although, the rudiments of the legal framework of the ECOWAS is being taught in law schools across Africa, it is recommended the introduction of the studies of regional economic integration and the role community institutions into the curricula of law schools.

- The actions of the WAEMU countries may put an end to the decision of a single currency in Africa as the WAMZ countries have withdrawn from the initiative. This informs the need for the West African countries to break free completely from its colonial masters before this exercise can work. It would thereby take a considerable effort for the single currency agenda to work within the ECOWAS region.

Cite this article as: A detutu Talabi (2021). Eco: TheSingle Currency A genda in West A frica. International J ournal of A frican Studies. 1(3), 62-66. doi: 10.51483/ IJAFRS.1.3.2021.62-66. 